\title{
ANALISIS KEBUTUHAN BAHAN AJAR BAHASA ARAB BAGI CALON TENAGA KERJA INDONESIA (TKI) DI TIMUR TENGAH
}

\author{
Nuruddin \\ Jurusan Bahasa dan Sastra Arab Universitas Negeri Jakarta
}

\begin{abstract}
This study is to describe the needs to develop Arabic language teaching materials for prospective Indonesian migrant workers in Middle East. It is a research and development study adapted from Borg and Gall with the following procedures: reviewing relevant literature, conducting a field observation, studying some collected documentation, and in-depths interviews. The results of the study show that (1) the teaching materials are geared to help the prospective Indonesian migrant workers to communicate, to make their tasks at ease, to understand the culture and customs and relevant documents on employment; (2) the teaching materials are designed as multimedia products; and (3) the teaching materials are developed based on cultural themes and approach.
\end{abstract}

Keywords: arabic learning materials, culture-based materials, interactive multimedia.

\begin{abstract}
Abstrak: Penelitian ini bertujuan mendeskripsikan kebutuhan bahan ajar bahasa Arab bagi calon tenaga kerja Indonesia (TKI) di Timur Tengah. Penelitian menggunakan pendekatan pengembangan model Borg dan Gall, dengan langkahlangkah: mereviu literatur, observasi lapangan, studi dokumentasi, dan wawancara. Data yang diperoleh dianalisis menjadi bahan utama dalam mendesain bahan ajar. Hasil penelitian meliputi pertama, bahan ajar diarahkan untuk: membantu komunikasi dengan majikan, mempermudah tugas TKI, memahami budaya, adat istiadat, dan naskah-naskah ketenagakerjaan. Kedua, bahan ajar didesain dengan multimedia dalam bentuk audio dan video. Ketiga, bahan ajar dibuat dengan pendekatan dan tema-tema budaya.
\end{abstract}

Kata Kunci: bahan ajar bahasa arab, berbasis budaya, multimedia interaktif.

Bahan ajar merupakan salah satu dari tujuh komponen pengajaran. Tujuh komponen pengajaran tersebut adalah kurikulum, guru, siswa, bahan ajar, media, strategi dan teknik pembelajaran, serta evaluasi (Susanto, 2007:233). Bahan ajar memiliki kontribusi yang tinggi kepada pencapaian tujuan pembelajaran. Oleh karena itu, bahan ajar harus didisain dengan baik sesuai dengan tujuan yang ingin dicapai.

Bahan Ajar bahasa Arab bagi calon TKI di negara-negara Timur Tengah sampai sekarang belum berbasis budaya Arab. Bahan ajar tersebut belum dirancang untuk lebih 
memudahkan calon TKI dalam mempelajarinya. Teknologi multimedia yang saat ini berkembang pesat juga belum dimanfaatkan dalam pembelajaran. Hal ini mengakibatkan pelajaran bahasa Arab dirasa sulit, tidak efektif dan cenderung membosankan.

Penguasaan terhadap bahasa Arab berbasis budaya pada era globalisasi-era dimana sekat dan batas-batas teritori sudah hilang--menjadi sangat penting bagi calon TKI di luar negeri. Budaya atau kebudayaan dalam pandangan Koentjaraningrat (1992) memiliki tiga wujud, yaitu wujud gagasan yang berbentuk sisitem budaya yang bersifat abstrak, wujud perilaku yang membentuk sistem sosial yang bersifat lebih kongkret, dan wujud benda yang membentuk kebudayaan fisik.

Dalam pengajaran bahasa Arab berbasis budaya Arab ini para TKI tidak hanya dibekali kemahiran berbahasa Arab melainkan juga dibekali pengetahuan tentang ketiga wujud kebudayaan sebagaimana dikemukakan Koentjaraningrat di atas. Pemberian bekal tentang budaya tersebut secara sederhana mengacu kepada adat istiadat dan budaya negara yang dituju, yaitu negara-negara Timur Tengah.

Skinner (dalam Mahmudah, 2010: 72) menyatakan bahwa pemerolehan bahasa dan karakter perilaku seseorang sebagian besar dipengaruhi oleh lingkungan sekitar. Dengan demikian, bahwa budaya yang ada dalam lingkunganlah yang membentuk kemampuan berbahasa dan karakter manusia lewat proses perangsang yang terjadi antara manusia dan lingkungan. Pandangan Skinner tersebut didukung oleh Chaer (2012: 66) yang menyatakan bahwa kefasihan seseorang dalam berbahasa sangat bergantung pada adanya kesempatan (lingkungan) untuk menggunakan bahasa tersebut. Jika kesempatannya banyak, maka kefasihannya bertambah baik. Jika kesempatannya berkurang atau sedikit maka kefasihannya akan berkurang. Oleh karena itu, pembelajaran bahasa Arab sebagai bahasa asing bagi TKI di Negara Timur Tengah akan dengan mudah jika dilakukan melalui interaksi dengan lingkungan Negara tersebut sehingga yang diperoleh lebih maksimal.

Bahan ajar dalam pandangan Tomlinson (1998: 2) adalah segala sesuatu yang digunakan pengajar atau pemelajar untuk memudahkan belajar bahasa dan meningkatkan pengetahuan serta pengalaman berbahasa. Bahan ajar bahasa Arab mengacu pada pandangan Tomlinson di atas berarti segala sesuatu yang digunakan pengajar atau pemelajar untuk memudahkan belajar bahasa Arab.

Bahan ajar bahasa Arab yang didesain berbasis budaya (Arab) ini sangat diharapkan keberadaannya untuk menjawab akar permasalahan TKI di Timur Tengah.Sebagaimana dikemukakan oleh mantan Menakertrans, Erman Suparno "Ada dua akar permasalahan TKI di Timur Tengah. Pertama, TKI kurang siap dalam hal keterampilan, bahasa, dan pengetahuan tentang adat istiadat dan budaya negara penempatan. Kedua, sebagian PJTKI tidak benar-benar melatih calon TKI" (http://www.aksesdeplu.com/bekali\%20diri20laput\%20edisi\%20.htm).

Sejalan dengan hal tersebut mantan Ketua PBNU, Hasyim Muzadi meminta kepada pemerintah agar lebih memperhatikan para TKI dengan membekali pengetahuan, adat istiadat, dan budaya negara setempat sebelum mereka diberangkatkan ke luar negeri. Pasalnya, perbedaan budaya antara Indonesia dengan negara yang ditempati kerja, merupakan masalah tersendiri bagi para TKI tersebut. "Di Arab Saudi, orang Arab berpikir bahwa ketika mereka mempekerjakan TKI, berarti mereka sudah membelinya. Artinya, kalau sudah dibeli, mereka berpikir, maka mau diapa-apain pun tidak masalah," (http://www.nu.or.id/page.php?lang=id\&menu=newsview\&newsid=12399). Permasalahan pokok tersebut harus direspon secara positif oleh berbagai pihak terutama para akademisi 
dengan melakukan penelitian yang dapat menghasilkan produk penelitian berupa model pembelajaran bahasa Arab berbasis budaya.

Di sisi lain, Multimedia sebagai suatu sistem teknologi yang menggabungkan berbagai sumber media yaitu teks, grafik, suara, animasi, video yang disampaikan dan dikontrol sistem komputer secara interaktif dapat dimanfaatkan dalam pembelajaran untuk memecahkan masalah-masalah belajar. Sebagaimana kebanyakan sistem mengajar, komputer dapat digunakan sebagai alat mengajar terutama untuk memberi penguatan belajar awal, merangsang dan memotivasi belajar, atau untuk berbagai jenis kemungkinan lainnya (Lee \& Owens, 2004:181). Selain itu multimedia juga dapat dimanfaatkan sebagai media yang efektif untuk menumbuhkan minat, motivasi, dan kreativitas bagi penggunanya. Melalui software yang di dalamnya berisi rancangan pembelajaran yang baik, komputer mampu berperan lebih baik.

Multimedia interaktif dapat digunakan sebagai alternatif penting untuk mendampingi metode klasikal yang biasanya digunakan dosen dalam mengajar di kelas. Media interaktif ini dapat digunakan sebagai media bantu untuk menampilkan, memberikan penguatan materi, dan alat untuk mengukur materi yang dipelajari, biasanya ditampilkan dengan elemen yang interaktif. Menurut Alessi \& Trollip (1985: 60) program yang baik haruslah meliputi empat aktivitas yaitu: (1) informasi (materi pelajaran) harus diberikan, (2) siswa harus diarahkan, (3) siswa diberi latihan, (4) pencapaian belajar harus dinilai.

Pada dasarnya, komputer sebagai media pokok multimedia tidak mengandung nilai dalam dirinya sendiri, semuanya sangat tergantung bagaimana manusia merancang, memanfaatkan, dan menerimanya. Kenyataannya komputer dapat memperingan dan telah memberikan manfaat yang luar biasa dalam berbagai aspek kehidupan manusia (Heinich, 1996).

Dalam bidang pendidikan, inovasi pendayagunaan teknologi ini dapat dimanfaatkan sebagai media yang efektif untuk membantu orang belajar. Melalui software yang di dalamnya berisi rancangan pembelajaran yang baik, komputer mampu berperan sebagai media yang efektif untuk menumbuhkan minat, motivasi, dan kreativitas bagi penggunanya (Sudjana dan Rivai: 2002).

Kolaborasi bahan ajar dengan multimedia interaktif yang demikian diharapkan dapat memperkuat tujuan, peran, sikap, dan strategi yang akan digunakan para instruktur di BLKBLK PJTKI, sehingga pembelajaran dapat berjalan lebih efektif dan efesien. Berdasarkan latar belakang tersebut, peneliti membuat perumusan masalah penelitian, "Bagaimana identifikasi kebutuhanbahan ajar bahasa Arab berbasis budaya menggunakan multimedia interaktif bagi calon tenaga kerja Indonesia (TKI) di Timur Tengah?"

\section{METODE PENELITIAN}

Berdasarkan permasalahan di atas, fokus penelitian ada dua, yaitu: pertama, melakukan analisis kebutuhan bahan ajar bahasa Arab bagi calon tenaga kerja Indonesia di Timur Tengah, dan kedua, menghasilkan model bahan ajar bahasa Arab bagi calon tenaga kerja Indonesia di Timur Tengah. Kedua fokus tersebut dilaksanakan pada dua tahapan dan tahun anggaran yang berbeda.

Analisis kebutuhan bahan ajar bahasa Arab ini merupakan penelitian tahun pertama, maka tujuan penelitian ini adalah terbatas pada fokus yang pertama, yaitu: menghasilkan analisis kebutuhan bahan ajar bahasa Arab bagi calon TKI di Timur Tengah. Untuk mencapai tujuan tersebut penelitian didesain dengan pendekatan penelitian dan 
pengembangan model Borg dan Gall (2003). Dalam pandangan Borg dan Gall model penelitian dan pengembangan ialah suatu proses yang digunakan untuk mengembangkan dan memvalidasi produk-produk pendidikan, misalnya silabus bahan pembelajaran, buku teks, metode pembelajaran, dan lain-lain yang dilakukan dalam suatu siklus penelitian dan pengembangan.

Langkah-langkah penelitian ini terbatas pada langkah awal, yaitu research and information collecting. Pada langkah ini peneliti melakukan pengumpulan informasi melalui reviu literatur, observasi lapangan, studi dokumentasi, wawancara kepada TKI yang berjumlah 20 orang, instruktur bahasa Arab di BLK PJTKI yang berjumlah tiga orang, dan orang Arab yang menjadi pengguna jasa TKI yang berjumlah 5 orang. Penggalian data dari orang Arab dilakukan dengan cara menelpon langsung kepada responden yang tinggal di Arab Saudi dengan panduan angket wawancara yang telah dipersiapkan.

Data penelitian juga diperoleh dari angket yang diisi oleh mantan TKI dan instruktur bahasa Arab di BLK-BLK PJTKI.Data dari kedua kelompok sumber tersebut dikonfirmasi kepada orang Arab yang memperkejakan TKI di rumahnya. Konfirmasi ini dilakukan untuk mensingkronkan data penelitian supaya hasil yang diperoleh benar-benar valid.

\section{HASIL PENELITIAN}

Hasil analisis kebutuhan bahan ajar bahasa Arab bagi calon TKI ini dibagi menjadi tiga bagian, yaitu pertama, aspek terkait dengan isi bahan ajar; kedua: aspek budaya Arab, dan ketiga, aspek multimedia.

\section{Isi Bahan Ajar}

Uraian mengenaiisi bahan ajar meliputi tujuan pembelajaran, kompetensi bahasa yang harus dikuasai, bahan ajar, sumber belajar, evaluasi pembelajaran, dan pengembangan bahan ajar. Paparan masing-masing adalah sebagai berikut.

\section{Tujuan Pembelajaran}

Seluruh responden mengatakan bahwa tujuan mempelajari bahasa Arab bagi TKI di Negara Timur Tengah adalah untuk membantu berkomunikasi dengan keluarga majikan, mempermudah mengerjakan tugas-tugas sebagai TKI, dan membantu memahami naskahnaskah adiministrasi ketenagakerjaan, misalnyapasport, visa, dan surat-surat penting lainnya, dan mempermudah memahami budaya dan adat istiadat lokal. Hasil analisis angket yang telah diisi oleh responden dituangkan dalam table 1.

Seluruh responden baik instruktur, TKW, dan majikan menjawab bahwa pembelajaran atau pembekalan kemampuan berbahasa Arab bagi calon TKI perlu diarahkan kepada keempat tujuan, yaitu: (a) menjadikan TKI mampu berkomunikasi dengan keluarga majikan, (b) mempermudah mengerjakan tugas-tugas sebagai TKI, (c) membantu memahami naskah-naskah administrasi ketenagakerjaan, misalnya passport, visa, dan suratsurat penting lainnya, dan (d) mempermudah memahami budaya dan adat istiadat lokal.

Dengan beberapa tujuan di atas diharapkan para TKI dapat menjalankan tugas-tugasnya sebagai tenaga kerja dengan sebaik-baiknya. Salah satu instruktur bahasa Arab mengemukakan "intinya biar TKI paham apa yang disuruh oleh majikan dan ngga dibegobegoin kalau tiba-tiba disuruh tanda tangan dokumen ini itu". 
Data di lapangan menunjukkan bahwa jam pembelajaran bahasa Arab di BLK bagi calon TKI sangat terbatas. Hal itu diungkapkan salah satu instruktur (FaS) berikut: "Terkadang BLK hanya memberi waktu untuk belajar komunikasi bahasa Arab sangat singkat sekali waktunya, sehingga banyak dari TKI kita yang merasa kesulitan berkomunikasi".

Tabel 1: Tujuan Pembelajaran bahasa Arab bagi Calon TKI

\begin{tabular}{cllll}
\hline No & $\begin{array}{l}\text { Tujuan mempelajari Bahasa Arab } \\
\text { bagi TKI }\end{array}$ & Instruktur & TKI & Majikan \\
\hline $\mathbf{1}$ & $\begin{array}{l}\text { Membantu berkomunikasi dengan } \\
\text { keluarga majikan }\end{array}$ & Perlu & Perlu & Perlu \\
$\mathbf{2}$ & $\begin{array}{l}\text { Mempermudah mengerjakan tugas- } \\
\text { tugas sebagai TKI }\end{array}$ & Perlu & Perlu & Perlu \\
$\mathbf{3}$ & $\begin{array}{l}\text { Membantu memahami naskah-naskah } \\
\text { adiministrasi ketenaga-kerjaan, seperti } \\
\text { pasport, visa, dan surat-surat penting } \\
\text { lainnya. }\end{array}$ & Perlu & Perlu & $\begin{array}{l}\text { Kadang- } \\
\text { kadang }\end{array}$ \\
$\mathbf{4} \begin{array}{l}\text { Mempermudah memahami budaya dan } \\
\text { adat istiadat lokal }\end{array}$ & $\begin{array}{l}\text { Kadang- } \\
\text { kadang }\end{array}$ & Perlu & Perlu \\
\hline
\end{tabular}

\section{Kompetensi Bahasa TKI}

Berdasarkan data yang diperoleh diketahui bahwa kompetensi bahasa Arab yang sangat diperlukan oleh calon TKI adalah kemahiran menyimak dan berbicara. Kemahiran membaca dan menulis bagi calon TKI kadang-kadang saja dibutuhkan. Hal tersebut terungkap dalam hasil wawancara tertulis sebagaimana disajikan pada tabel 2.

Tabel 02: Kompetensi Bahasa Arab bagi Calon TKI

\begin{tabular}{cllll}
\hline No & $\begin{array}{l}\text { Kompetensi bahasa Arab yang } \\
\text { harus dikuasai calon TKI }\end{array}$ & Instruktur & TKI & Majikan \\
\hline 1 & $\begin{array}{l}\text { Kompetensi } \\
\text { menyimak/mendengarkan }\end{array}$ & $\begin{array}{l}\text { Sangat } \\
\text { perlu }\end{array}$ & $\begin{array}{l}\text { Sangat } \\
\text { perlu }\end{array}$ & $\begin{array}{l}\text { Sangat } \\
\text { perlu }\end{array}$ \\
2 & Kompetensi berbicara & $\begin{array}{l}\text { Sangat } \\
\text { perlu }\end{array}$ & $\begin{array}{l}\text { Sangat } \\
\text { perlu }\end{array}$ & $\begin{array}{l}\text { Sangat } \\
\text { perlu }\end{array}$ \\
& Perlu & $\begin{array}{l}\text { Sangat } \\
\text { perlu }\end{array}$ & $\begin{array}{l}\text { Kadang- } \\
\text { kadang }\end{array}$ \\
& Kompetensi membaca & Kadang- & $\begin{array}{l}\text { Sangat } \\
\text { Kadang- } \\
\text { kadang }\end{array}$ \\
\hline
\end{tabular}

Ketiga kelompok responden; instruktur, TKI, dan majikan menjawab bahwa kemahiran menyimak dan berbicara sangat dibutuhkan oleh calon TKI karena kemahiran inilah yang berkaitan langsung dengan tugas pekerjaan sebagai tenaga kerja rumah tangga keluarga. Mereka selalu berkomunikasi dengan majikan dan keluarganya. Sebaliknya, dua kemahiran yang lain; kemahiran membaca dan menulis kadang-kadang saja dibutuhkan oleh TKI. 


\section{Konten Bahan Ajar}

Berdasarkan studi dokumentasi terhadap draf kurikulum Menakertrans, diperoleh data bahwa rancangan bahan ajar bahasa Arab untuk TKI bidang rumah tangga keluarga mencakup: (a) pengucapkan bunyi-bunyi bahasa Arab, (b) komunikasi sederhana dalam Bahasa Arab, (c) komunikasi harian dalam bahasa Arab dengan anggota keluarga majikan, (d) komunikasi harian yang terkait dengan penggunaan dan perawatan alat-alat rumah tangga, (e) komunikasi ketika menghidangkan makanan dan minuman, (f) komunikasi ketika membuat makanan dan minuman, (g) komunikasi ketika menerima tamu, dan (h) kominikasi terkait dengan dokumen ketenagakerjaan, seperti passport, visa, dan dokumen yang lain.

Ketika rancangan isi bahan ajar bahasa Arab untuk calon TKI ini dikonfirmasi kepada ketiga kelompok responden, semuanya menjawab bahwa bahan tersebut di atas sudah cukup. Kerangka bahan ajar Bahasa Arab untuk TKI tersebut kemudian dibagi menjadi tiga kompetensi. Pertama, kompetensi umum; terdiri atas kemampuan mengucapkan bunyibunyi bahasa Arab dan kemampuan melakukan komunikasi sederhana dalam bahasa Arab. Kedua: komptensi inti; yang terdiri atas kemampuan berkomunikasi harian dalam bahasa arab dengan anggota keluarga majikan, kemampuan berkomunikasi harian yang terkait dengan penggunaan dan perawatan alat-alat rumah tangga, kemampuan berkomunikasi ketika menghidangkan makanan dan minuman, kemampuan berkomunikasi ketika membuat makanan dan minuman, dan kemampuan berkomunikasi ketika menerima tamu. Ketiga, kompetensi khusus, yaitu kemampuan berkominikasi terkait dengan dokumen ketenagakerjaan, misalnya passport, visa, dan dokumen yang lain.

Untuk meningkatkan pemahaman pembelajar terhadap materi dalam bahan ajar sebagaimana diungkap diatas, bahan ajar perlu dilengkapi daftar kosakata, ringkasan setiap materi, dan penjelasan dalam bentuk audio dan video. Hal itu tergambar dalam hasil wawancara peneliti dengan instruktur bahasa Arab yang menjadi responden kelompok pertama. Hasil penggalian data melalui wawancara tersebut menunjukkan bahwa ketiga instruktur menyatakan perlunya daftar kosakata dan penjelasan materi dalam bentuk audio. Dua instruktur menyatakan perlunya ringkasan materi pada bahan ajar. Sebaliknya, tentang daftar diagram/tabel, ilustrasi/foto, atau penjelasan dalam bentuk video dua dari tiga instruktur menyatakan tidak perlu.

Jawaban tersebut menunjukkan bahwa daftar kosa kata, ringkasan, penjelasan berbentuk audio perlu disediakan di dalam bahan ajar bahasa Arab bagi calon TKI. Jika memungkinkan penjelasan tersebut berupa video. Penggunaan gambar/foto, bahan otentik, misalnya form isian kependudukan, aplikasi perbankan juga diperlukan dalam bahan ajar bahasa Arab karena dapat membantu mempermudah dalam memahami bahan ajar.

\section{Evaluasi Proses Pembelajaran}

Kegiatan pembelajaran apapun perlu dievaluai untuk mengetahui hasil atau capaian yang diperoleh. Evaluasi itu penting untuk mengukur tingkat keberhasilan peserta didik. Kelompok responden instruktur bahasa Arab di PJTKI menjelaskan bahwa untuk mengetahui tingkat kemampuan peserta pelatihan bahasa Arab (calon TKI), perlu dilakukan evaluasi/tes akhir dalam proses pembelajaran. Ketiga instruktur menyatakan bahwa evaluasi itu perlu dilakukan melalui tes tulis, tes lisan, tes performansi (penggunaan bahasa dalam situasi konkrit). 
Dalam mengerjakan tugas tugas-tugas rumah tangga, para TKI selalu berinteraksi dan berkomunikasi dengan majikan dan keluarganya. Karena itu, tes lisan dan tulis perlu dilakukan. Lebih dari itu, menurut salah satu rensponden tes lisan perlu diperbanyak waktunya, dan akan lebih baik yang melakukan tes adalah nativenya langsung.

\section{Pengembangan Bahan Ajar}

Tentang bahan ajar, para instruktur bahasa Arab di PJTKI secara keseluruhan mengatakan bahwa bahan ajar yang selama ini mereka gunakan sangat perlu dikembangkan. Bentuk-bentuk pengembangannya adalah: (a) didesain dengan multimedia, b) dikembangkan dengan pendekatan budaya, (c) bersifat kontekstual, dan (d) disesuaikan dengan tujuan pembelajaran.

Ketiga instruktur menyatakan bahwa bahan ajar sangat perlu disesuaikan dengan tujuan pembelajaran. Terkait desain bahan ajar berbasis multimedia, dua instruktur menyatakan sangat perlu. Berbeda dengan itu, tentang penggunaan budaya dalam pengembangan bahan ajar dan kontekstualitas bahan ajar, para instruktur berbeda pendapat. Sebagian menyatakan sangat perlu dan sebagian menyatakan perlu atau bahkan tidak perlu.

\section{Metode Belajar}

Dari hasil wawancara dengan kelompok responden instruktur dan TKW terungkap bahwa metode yang digunakan oleh instruktur bahasa Arab memberikan pengaruh kepada peserta dalam memahami materi, karena metode yang baik dapat memberikan daya tarik bagi peresta di dalam mengikuti proses pembelajaran. Di antara metode dalam pembelajaran bahasa (Arab) yang dapat memberikan daya tarik dan memudahkan peserta memahami bahan ajar menurut para instruktur adalah memanfaatkan multimedia. Berbeda dengan itu, menurut calon TKI metode yang menarik adalah metode ceramah dan diskusi. Jawaban para calon TKI tersebut karena mereka belum memahami apa itu multimedia.

Seorang instruktur terutama dalam bahasa sangat diharapkan untuk selalu kreatif dan aktif dalam meningkatkan metode mengajarnya supaya peserta didiknya tertarik, tidak cepat bosan, dan cepat memahami materi. Sebagaimana terungkap dalam saran dan komentar responden dari kelompok instruktur sebagai berikut: "Cara apa saja bisa digunakan asal instruktur mau aktif dan kreatif” (wawancara dengan ScR, 15-10-2012). Selain itu faktor pendidikan TKI juga penting untuk mengembangkan berbagai macam metode. Akan tetapi dalam kenyataannya para TKI sangat rendah pendidikannya. Oleh karena, itu metode yang bervariasi sangat tepat untuk mengajarkan bahasa Arab kepada mereka. Sebagaimana saran salah satu responden "...menurut saya metode diskusi dan ceramah kurang efektif, karena diantara mereka banyak yang tidak sekolah, sehingga mereka kurang memahami jika diajar dengan metode diskusi atau ceramah" (Wawancara dengan FaS, 15-10-2012).

\section{Aspek Budaya}

Pada bagian ini diuraian dua hal pokok, yaitu konsep budaya Arab dan tema-tema materi budaya Arab. Uraian masing-masing adalah sebagai berikut. 


\section{Konsep Budaya Arab}

Pada aspek budaya Arab ini peneliti terlebih dahulu menanyakan kepada ketiga kelompok responden tentang istilah "budaya Arab". Semua responden menjawab mengenal istilah budaya Arab. Perspektif budaya perlu dimasukkan dalam kerangka bahan ajar bahasa Arab bagi para calon TKI, karena dapat membantu memahami karakter dan bahasa masyarakat Arab.

Dari wawancara dengan ketiga kelompok responden, yaitu instruktur, TKI, dan majikan diperoleh informasi bahwa mereka secara umum menjawab bahwa bahan ajar bahasa Arab bagi calon TKI perlu atau bahkan sangat perlu dikembangkan berbasis budaya. Jawaban responden tersebut menggambarkan bahwa buku ajar bahasa Arab untuk calon TKI/TKW di Timur Tengan sangat perlu atau setidaknya perlu didesain dengan perspektif budaya Arab. Demikian juga menurut majikan sebagai pengguna jasa TKW.

\section{Tema-Tema Materi Budaya Arab}

Mengenai tema-tema dalam aspek budaya Arab, peneliti mendapat jawaban yang hampir sama dari para responden, yang mengerucut pada lima tema, yaitu: interaksi dalam kehidupan sehari-hari, sopan santun bahasa, pakaian, makanan/kuliner, dan agama. Sesuai dengan perolehan data dari instruktur, majikan, dan TKI tersebut, aspek budaya yang akan dimasukkan dalam bahan ajar bahasa Arab yang akan dikembangkan adalah: (a) interaksi dalam kehidupan sehari-hari, (b) pakaian, (c) makanan/kekerabatan/pendidikan, (d) sopan santun bahasa, dan (e) agama.

\section{Aspek Multimedia}

Selain aspek budaya Arab, bentuk pengembangan bahan ajar bahasa Arab untuk calon TKI/TKW yang dapat memberikan daya tarik dan mempermudah dalam mempelajarinya adalah aspek multimedia. Multimedia digunakan untuk melengkapi bahan ajar supaya para calon TKI yang menjadi peserta BLK di PJTKI menjadi tertarik, tidak bosan, dan mudah memahami bahan ajar tersebut.

Dalam hal ini, semua kelompok responden (instruktur, TKI, dan majikan) menyatakan bahwa bahan ajar berupa multimedia memberikan daya tarik dan kemudahan bagi peserta dalam mempelajari bahasa Arab. Selain aspek multimedia, para responden juga menyatakan perlunya bahan ajar dilengkapi dengan tampilan audio dan video supaya semakin menarik para pembelajar.

\section{PEMBAHASAN}

Bahan ajar bahasa Arab untuk calon TKI yang akan dikirim ke Timur Tengah perlu dikembangkan. Pengembangan bahan ajar ini dengan spesifikasi khusus pada tujuan, desain, dan aspek budaya. Pertama, aspek terkait dengan isi bahan ajar yang meliputi tujuan pembelajaran, kompetensi bahasa yang harus dikuasai TKI, bahan ajar, sumber belajar, evaluasi pembelajaran, dan pengembangan bahan ajar; kedua: aspek budaya Arab, dan ketiga, aspek multimedia.

\section{Isi Bahan Ajar}

Bahan ajar merupakan salah satu aspek penting dalam pembelajaran bahasa. Bahan ajar bagi calon TKI diperlukan agar mereka memahami berbagai hal yang terkait dengan 
pekerjaannya kelak. Dalam proses pembelajaran bahasa Arab, bahan ajar merupakan salah satu unsur yang sangat penting. Bahan ajar disusun dengan memperhatikan aspek isi materi pelajaran. Isi materi meliputi tujuan pembelajaran, kompetensi bahasa yang harus dikuasai TKI, bahan ajar, sumber belajar, evaluasi pembelajaran. Dalam penyusunan bahan ajar aspek-aspek tersebut perlu untuk diperhatikan agar pembelajaran bahasa Arab bagi TKI berjalan sesuai dengan tujuan. Hal tersebut sesuai dengan teori yang menyatakan bahwa pembelajaran adalah suatu kombinasi unsur-unsur manusiawi, material, fasilitas, perlengkapan, dan prosedur yang saling mempengaruhi untuk mencapai tujuan pembelajaran (Hamalik, 2009: 57). Jadi faktor isi bahan ajar menjadi faktor yang mempengaruhi tercapainya tujuan pembelajaran bahasa Arab. Sejalan dengan pernyataan ini Kholisin (2011:29) mengemukakan bahwa salah satu faktor yang perlu dicurigai sebagai penghambat motivasi pebelajar adalah bahan ajar.

Salah satu bagian dari isi bahan ajar yaitu tujuan pembelajaran. Dijelaskan oleh Basyir dkk (1415 H: 22-25), bahwa tujuan pembelajaran adalah deskripsi obyektif tentang bentuk perubahan yang diharapkan pada diri pembelajar setelah malalui pengalaman belajar. Berdasarkan hasil penelitian ditemukan bahwa seluruh responden baik instruktur, TKW, dan majikan menjawab bahwa pembelajaran atau pembekalan kemampuan berbahasa Arab bagi calon TKI perlu diarahkan kepada keempat tujuan, yaitu: (a) menjadikan TKI mampu berkomunikasi dengan keluarga majikan, (b) mempermudah mengerjakan tugas-tugas sebagai TKI, (c) membantu memahami naskah-naskah administrasi ketenagakerjaan, misalnya passport, visa, dan surat-surat penting lainnya, dan (d) mempermudah memahami budaya dan adat istiadat lokal.

Kompetensi bahasa juga menjadi faktor penting untuk tercapainya keberhasilan pembelajaran. Pinker (dalam Brown 2008:6) mengemukakan bahwa bahasa adalah keterampilan khusus yang kompleks, berkembang dalam diri anak-anak secara spontan, tanpa usaha sadar atau instruksi formal, dipakai tanpa memahami logika yang mendasarinya, secara kualitatif sama dalam diri setiap orang, dan berbeda dari kecakapan lain yang sifatnya lebih umum dalam hal memproses informasi atau berperilaku secara cerdas. Dari pengertian ini dapat dipahami bahwa bahasa melibatkan banyak faktor keterampilan yang kompleks dan secara umum dapat dikuasai dengan cara yang sama.

Berdasarkan hasil penelitian ditemukan bahwa kompetensi bahasa Arab yang sangat diperlukan oleh calon TKI adalah kemahiran menyimak dan berbicara. Kemahiran membaca dan menulis bagi calon TKI kadang-kadang saja dibutuhkan. Temuan penelitian tersebut sesuai dengan teori mengenai kompetensi bahasa menurut Kumaravadivelu (2006:17) yang mengemukakan ada empat komponen kompetensi dalam hal pengajaran dan pembelajaran bahasa yaitu: pertama kompetensi gramatikal, kompetensi sosiolinguistik, kompetensi wacana, dan kompetensi strategis. Kempat kompetensi tersebut perlu dimiliki oleh TKI agar TKI memiliki kemahiran menyimak, berbicara, membaca dan juga sekaligus menulis. Seperti juga dijelaskan bahwa proses pembelajaran bahasa seharusnya juga melalui tahapan seperti tersebut, yaitu mulai dari belajar mendengar, berbicara, membaca, dan menulis (Makruf, 2009:19).

Kemudian konten juga menjadi aspek yang penting dalam penyusunan bahan ajar. Dijelaskan juga oleh Basyir (1415 H: 22-25) bahwa bahan ajar adalah nilai-nilai pendidikan dan pengetahuan yang harus dikuasai oleh pembelajar sesuai dengan tujuan. Bahan ajar disusun agar tujuan pembelajaran tercapai. Temuan penelitian menunjukkan bahwa daftar kosa kata, ringkasan, dan penjelasan berbentuk audio perlu disediakan di dalam bahan ajar bahasa Arab bagi calon TKI. Hal tersebut dijelaskan juga dalam teori yang menyatakan 
bahwa terdapat unsur-unsur dan keterampilan yang diajarkan dalam pembelajaran bahasa. Dalam unsur bahasa terdapat tata bunyi (fonologi/'ilm al-ashwat), tata tulis (ortografi/kitabat al-huruf), tata kata (al-sharf), tata kalimat (nahwu), dan kosa kata (almufrodat). Sedangkan keterampilan berbahasa terdiri atas membaca (al-qira'ah), menulis (al-kitabah), berbicara (al-kalam), dan menyimak (al-istima') (Effendy 2009:102). Jadi dalam penyusunan bahan ajar, pengembang perlu memperhatikan konten bahan ajar yang meliputi unsur-unsur bahasa yaitu salah satunya mengenai pemahaman kosa kata yang diajarkan dengan menggunakan media berupa audio.

Aspek selanjutnya adalah evaluasi. Evaluasi menjadi salah satu aspek penting dalam pembelajaran yaitu sebagai alat untuk mengukur keberhasilan pembelajaran. Hasil penelitian menunjukkan bahwa untuk mengetahui tingkat kemampuan peserta pelatihan bahasa Arab (calon TKI), perlu dilakukan evaluasi/tes akhir dalam proses pembelajaran. Seperti juga dijelaskan oleh Basyir dkk (1415 H: 22-25) bahwa evaluasi adalah proses menghimpun data guna memastikan terwujudnya tujuan yang telah dirumuskan. Suatu keberhasilan dalam proses pembelajaran akan diketahui hasilnya ketika melakukan evaluasi. Sehingga evaluasi dalam pembelajaran bahasa Arab perlu dilakukan untuk mengetahui keberhasilan TKI dalam belajar.

Ada beberapa bentuk pengembangan bahan ajar yang di antaranya adalah: (1) bahan ajar didesain dengan multimedia, (2) bahan ajar dengan pendekatan budaya, (3) bahan ajar harus kontekstual, dan (4) bahan ajar harus disesuaikan dengan tujuan pembelajaran. Pengembangan bahan ajar menggunakan multimedia merupakan salah satu cara yang tepat untuk dilakukan. Melalui multimedia, TKI akan lebih mudah memahami bahasa Arab yang diajarkan. Kemudian bahan ajar juga dikembangkan dengan pendekatan budaya. Hal tersebut agar TKI memahami budaya Arab. Selain itu bahan ajar juga harus kontekstual dan sesuai dengan tujuan pembelajaran. Tujuan pengembangan bahan ajar tersebut disesuaikan dengan kebutuhan TKI dan untuk meningkatkan kemampuan belajar bahasa TKI. Hal tersebut dijelaskan juga oleh Tomlinson (1998:2) bahwa pemgembangan bahan ajar adalah apa yang dilakukan penulis, guru, siswa untuk memberikan sumber masukan berbagai pengalaman yang dirancang untuk meningkatkan belajar bahasa.

Aspek selanjutnya adalah metode belajar. Metode belajar juga menjadi aspek yang sangat diperlukan dalam pembelajaran bahasa Arab bagi TKI. Metode yang kreatif sangat diperlukan agar TKI lebih tertarik untuk belajar bahasa Arab. Kemudian dengan metode yang tepat juga akan memepermudah TKI dalam belajar bahasa Arab. Pengajar harus memilih metode yang tepat dalam pengajaran bahasa. Salah satu metode yang dapat digunakan adalah metode belajar dengan menggunakan media seperti misalnya komputer dan media yang lainnya. Hal tersebut sesuai dengan pendapat Effendy (2005:170) yang menyatakan bahwa untuk mempermudah siswa dalam mempelajari bahasa Arab yaitu salah satunya adalah menciptakan lingkungan bahasa Arab dengan lingkungan pandang dan dengar (audio-visual) yang dalam hal ini dapat diciptakan dengan memanfaatkan teknologi informasi. Jadi, pembelajaran bahasa Arab bisa memanfaatkan tekhnologi yang salah satunya dalam bentuk penggunaan multimedia.

\section{Aspek Budaya}

Budaya menjadi salah satu aspek penting dalam pembelajaran bahasa Arab bagi TKI. Hasil penelitian menunjukkan bahwa perspektif budaya perlu dimasukkan dalam kerangka bahan ajar bahasa Arab bagi calon TKI, karena dapat membantu memahami karakter dan 
bahasa masyarakat Arab. Mempelajari bahasa berarti mempelajari budaya. Budaya adalah sebuah cara hidup, ia adalah konten yang didalamnya manusiaberada, berpikir, merasa, dan berhubungan dengan yang lain. Ia adalah lem yang merekatkan sekelompok orang (Brown, 2008: 206). Budaya adalah keseluruhan ide canggih, keyakinan, kebiasaan, sikap, nilainilai, metode berpikir dan tindakan, dan sifat-sifat perilaku, inovasi atau metode dalam kehidupan di masyarakat (Jamous dan Chik, 2012:38). Bahasa dan budaya merupakan satu kesatuan yang tidak dapat dipisahkan. Bahasa merupakan awal dari terbentuknya sebuah budaya yang akhirnya membentuk suatu masyarakat. Bahasa bisa juga dikatakan sebagai identitas budaya suatu masyarakat. Bahasa merupakan sebuah identitas budaya, budaya lahir karena adanya bahasa, dan budaya ada karena adanya suatu masyarakat yang memiliki bahasa.

Bahasa merupakan bagian dari budaya sehingga ketika mempelajari bahasa Arab maka harus mempelajari pula mengenai budayanya. Hal tersebut juga disarankan oleh Harefa (2003:45) agar siswa yang mempelajari bahasa juga mempelajari budaya sebagai jalan untuk merasa, menginterpretasi, merasakan, dan berhubungan dengan siapa saja yang ditemui. Wekke (2015:289) menyatakan adanya kontribusi pemanfaatan aspek-aspek budaya dalam perkembangan belajar bahasa Arab peserta didik. Kemudian mengenai tematema dalam aspek budaya Arab dalam bahan ajar berkaitan dengan interaksi dalam kehidupan sehari-hari, sopan santun berbahasa, pakaian, makanan/kuliner, dan agama.

\section{Aspek Multimedia}

Selain aspek budaya Arab, bentuk pengembangan bahan ajar bahasa Arab untuk calon TKI/TKW yang dapat memberikan daya tarik dan mempermudah dalam mempelajarinya adalah aspek multimedia. Temuan penelitian menunjukkan bahwa bahan ajar berupa multimedia memberikan daya tarik dan kemudahan bagi peserta dalam mempelajari bahasa Arab. Selain aspek multimedia, para responden juga menyatakan perlunya bahan ajar dilengkapi dengan tampilan audio dan video supaya semakin menarik para pemelajar. Multimedia merupakan salah satu aspek yang diperlukan dalam pembelajaran bahasa Arab bagi calon TKI. Terdapat berbagai macam jenis media yang dapat digunakan untuk pembelajaran bahasa Arab. Hal tersebut ditegaskan juga dengan teori yang menjelaskan mengenai jenis-jenis media. Media pembelajaran menurut Harjanto (2005:237) dikelompokkan menjadi empat jenis, yakni: (1) media dua dimensi (grafis), seperti: gambar, foto, grafik, bagan, poster kartun, dan komik, (2) media tiga dimensi, seperti: model padat (solid model), model penempang, dan model susun, (3) media proyeksi, seperti: film, OHP, dan (4) lingkungan. Komputer merupakan salah satu jenis media yang dapat digunakan dalam pembelajaran bahasa Arab bagi calon TKI. Dijelaskan juga bahwa komputer dapat digunakan sebagai alat mengajar terutama untuk memberi penguatan belajar awal, merangsang dan memotivasi belajar, atau untuk berbagai jenis kemungkinan lainnya (Lee \& Owens, 2004:181). Menyadari akan pentingnya multimedia dan betapa besar manfaatnya dalam pembelajaran maka ia sangat perlu dikembangkan dalam pembelajaran bahasa Arab.Lebih dari itu, gaya guru dan metode pengajaran merupakan komponen penting dalam pengajaran bahasa yang memotivasi peserta didik (Aladdin, 2014:56) dengan memanfaatkan berbagai media pembelajaran yang tepat. 


\section{SIMPULAN}

Penelitian ini menyimpulkan bahwa bahan ajar bahasa Arab untuk calon TKI yang akan dikirim ke Negara-nagara Timur Tengah perlu dikembangkan. Bentuk-bentuk pengembangan bahan ajar ini berwujud pada beberapa hal, yaitu pertama, tujuan. Tujuan bahan ajar mengacu kepada: membantu berkomunikasi dengan keluarga majikan, mempermudah mengerjakan tugas-tugas sebagai TKI, mempermudah memahami budaya dan adat istiadat lokal, dan membantu memahami naskah-naskah adiministrasi ketenagakerjaan, seperti pasport, visa, dan surat-surat penting lainnya. Kedua: bahan ajar. Bahan ajar didesain dengan multimedia yang dilengkapi dengan daftar kosakata, ringkasan setiap materi, dan penjelasan dalam bentuk audio dan video. Ketiga, aspek budaya. Bahan ajar dibuat dengan pendekatan budaya, yang meliputi tema-tema sebagai berikut: tema interaksi dalam kehidupan sehari-hari, tema pakaian, makanan/kekerabatan/pendidikan, sopan santun berbahasa, dan agama.

\section{DAFTAR RUJUKAN}

Alessi, S. M. \& Trollip, S. R. 1985. Computer Based Instruction: Methods and Development. New Jersey: Prentice Hall.

Aladdin, A. 2014. The Importance of Immediate Learning Context: AnInvestigation on the Arabic as a Foreign Language Classroom. Dalam Jurnal Procedia - Social and Behavioral Sciences. Vol. 118 . Hal. $56-60$.

Basyir, M., Muzammil, Malik M., Sa'id, M. 1415 H. Madkhal ila al-Manahij wa Thuruq al-Tadris, Riyadh: Dar al-Liwa' li al-Nasyrwa al-Tauzi'.

Borg, W. R. \& Gall M. D. 2003. Education Research an Introduction. New York, Longman.

Brown, H. D. 2008. Prinsip Pembelajaran dan Pengajaran Bahasa. Terjemahan Noor Cholis dan Yusi Avianto Pareanom. Jakarta: Kedutaan Besar Amerika di Jakarta.

Chaer, A. 2012. Linguistik Umum (Edisi revisi). Jakarta. Rineka Cipta

Effendy, A. F. 2005. Metodologi Pengajaran Bahasa Arab. Malang: Misykat.

Effendy, A.F. 2009. Metodologi Pengajaran Bahasa Arab. Malang: Misykat.

Hamalik, O. 2009. Kurikulum dan Pembelajaran. Jakarta: Bumi Aksara.

Harefa, A. 2003. Mengasah Paradigma Pembelajar. Cetakan ke-2. Yogyakarta: Gradien.

Harjanto. 2005. Perencanaan Pengajaran. Jakarta: Aneka Cipta.

Heinich, R. 1996. Instructional Media and Technology for Learning. New Jersey: Prentice Hall.

(http://www.aksesdeplu.com/bekali\%20diri20laput-\%20edisi\%20.htm).

(http://www.nu.or.id/page.php?lang=id\&menu=newsview\&newsid=12399).

Jamous, R. \& Chik, A. R. 2012. Teaching Arabic for Cultural Purposes: A Case Study of Francophone Program of Arabic at Aleppo University. Dalam Jurnal Procedia - Social and Behavioral Sciences 66 , Hal. 37-45.

Kholisin. 2011. Pengembangan Model Pembelajaran Kalam Berbasis Cross Culture Understanding untuk Mahasiswa Program Studi Pendidikan Bahasa Arab. JURNAL AL ARABI. Vol. 9 No. 1, Juni 2011:28-38.

Koentjaraningrat. 1992. Kebudayaan, Mentalitas dan Pembangunan, Jakarta: Gramedia.

Kumaravadivelu, B. 2006. Understanding Language Teaching Lawrence Erlbaum Associates, Publishers, Mahwah. New Jersey London. 
Lee, W.W \& Owens, DL. 2004. Multimedia-Based Instructiononal Design Training Computer Based, Distance Broadcast Training, Performance Based Solution (2nd ). San Fransisco: Peiffera Wiley Imprin.

Mahmudah. 2010. Psikolinguistik; Kajian Teoretik. Makasar: Universitas Negeri Makasar

Makruf, I. 2009. Strategi Pembelajaran Bahasa Arab Aktif. Semarang: Needs Press.

Sudjana, Nana, \& Ahmad. R. 2002. Media Pengajaran. Bandung: Sinar Baru.

Susanto, G. 2007. Pengembangan Bahan Ajar BIPA Berdasarkan Kesalahan Bahasa Indonesia Pebelajar Asing. Dalam Jurnal BAHASA DAN SENI. Vol. 35 No. 2 Agustus 2007:231-239.

Tomlinson, B. (Ed.). 1998. Materials Development in Language Teaching. Cambrige: Cup. Wekke, S. I. 2015. Arabic Teaching and Learning: A Model From Indonesian Muslim Minority. Dalam Procedia - Social and Behavioral Sciences 191 . Hal. 286 - 290. 